\title{
Multi-Parameter Radar Observation of a Downburst Storm in Tokyo on 12 July 2008
}

\author{
Shin-ichi Suzuki, Takeshi Maesaka, Koyuru Iwanami, Ryohei Misumi, \\ Shingo Shimizu, and Masayuki Maki \\ National Research Institute for Earth Science and Disaster Prevention, Tsukuba, Japan
}

\begin{abstract}
Severe convective clouds developed in the Tokyo Metropolitan Area in the afternoon of 12 July 2008, and the storm produced F0 downbursts. Two X-band multi-parameter radars operated by the National Research Institute for Earth Science and Disaster Prevention (NIED) captured the structure of the wind and hydrometeors within the cloud, as well as their time evolutions. The storm had a multi-cellular appearance, and the radars captured the development of four separate cells. The existence of wet hail aloft within the updrafts is suggested from the high rainfall rate estimated from reflectivity compared with that from the specific differential phase.
\end{abstract}

\section{Introduction}

A downburst is a small-scale diverging wind feature that can generate damaging winds at the ground surface (Fujita 1981; Wilson and Wakimoto 2001). Ohno et al. (1996) analyzed 75 downbursts in Japan and summarized their features as follows: (1) all of these events were wet downbursts, (2) they occurred throughout Japan with a high concentration in July at around 1500 Japan Standard Time (JST), and (3) each storm event generally involved several downbursts.

On 12 July 2008, several convective storms developed in the south Kanto area of Japan. Strong winds associated with the convection resulted in damage in the Tokyo Metropolitan Area. Tokyo District Meteorological Observatory (2008) reported that several trees were broken, a crane was toppled, and a gondola used for building maintenance was damaged. The report also provided observation data of the storm collected by a Doppler radar located at Haneda Airport, $10 \mathrm{~km}$ south of the damaged area. Plan position indicater (PPI) scan data at an elevation angle of $0.7^{\circ}$ revealed strong horizontal divergence: the amplitude of both incoming and outgoing wind was about $20 \mathrm{~m} \mathrm{~s}^{-1}$. The region of divergence corresponded to the echo core of the storm. Based on these observations, it was inferred that the gust winds were associated with a downburst.

The National Research Institute for Earth Science and Disaster Prevention (NIED) operates two X-band multi-parameter radars (polarimetric Doppler radars): the EBN radar is located at Ebina City $\left(35.4^{\circ} \mathrm{N}, 139.4^{\circ} \mathrm{E}\right)$ (Maki et al. 2005), and came into operation in 2003, while the KSR radar, located at Kisarazu City $\left(35.4^{\circ} \mathrm{N}, 139.9^{\circ} \mathrm{E}\right)$, came into operation during the spring of 2008 . These two radars were suitably located to observe the downburstproducing storm that occurred on 12 July 2008 (Fig. 1), and on that day collected three-dimensional data by volume scan at 5 -min intervals. In addition to determining the types of hydrometeors from the dual polarimetric data, the dual Doppler data were expected to retrieve the three-dimensional wind associated with the storm.

Proctor (1989) investigated the importance of the type of precipition from numerical simulations of a microburst. Classification

Corresponding author: Shin-ichi Suzuki, National Research Institute for Earth Science and Disaster Prevention, 3-1 Tennoudai, Tsukuba, Ibaraki 305-0006, Japan. E-mail: ssuzuki@bosai.go.jp. (C2010, the Meteorological Society of Japan.

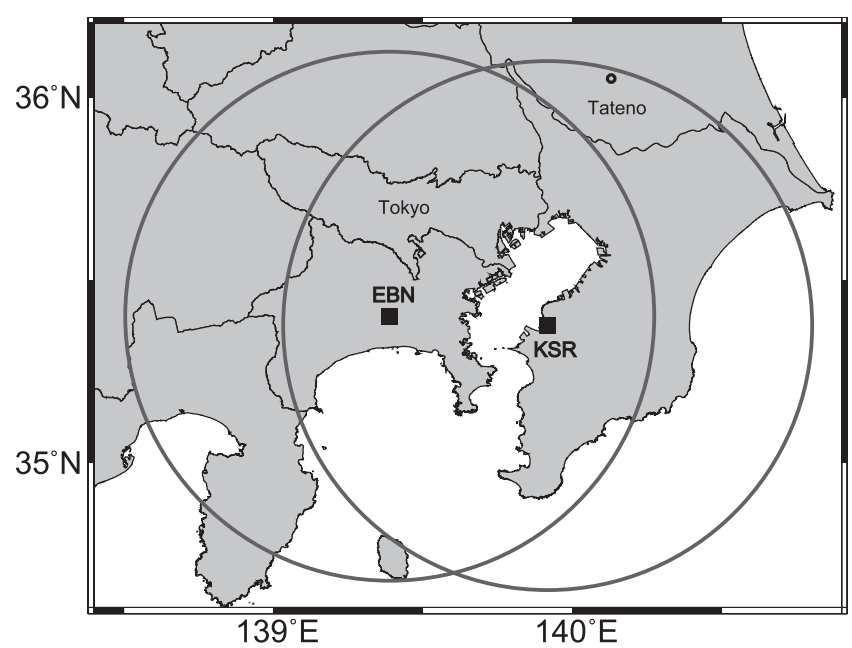

Fig. 1. Location of the EBN and KSR radars (closed squares) and their observation ranges of $80 \mathrm{~km}$ (circles).

of hydrometeors can be deduced well from several polarimetric variables (Straka et al. 2000). Wakimoto and Bringi (1988) observed the microburst-producing storm using a multiparameter radar, however, they focused on the differential reflectivity $\left(Z_{\mathrm{DR}}\right)$ only. This report is the first to describe wet downbursts observed by X-band polarimetric radars in Japan.

\section{Environmental situation}

Figure 2 shows a satellite image of water vapor over East Asia at $1500 \mathrm{JST}$. The eastward extension of a wet zone around $30^{\circ} \mathrm{N}-$ $40^{\circ} \mathrm{N}$ over the Asian continent was terminated around the Korean Peninsula by dry air from the north. This dry air in the upper troposphere covered the Japan Sea and Japanese islands.

Figure 3 shows a sounding of the atmosphere at Tateno, $60 \mathrm{~km}$ northeast of central Tokyo (Fig. 1), at 0900 JST on 12 July 2008. The air near the surface was not especially wet; however, the dry air in the upper troposphere provided favorable conditions for active convection in the Kanto area. Two capping inversions were formed at about 925 and $530 \mathrm{hPa}$, and the air above the inversion layers, especially above $530 \mathrm{hPa}$, was dry. The convective available potential energy (CAPE) of the parcel initially located at the surface, which was the largest value in this profile, was $1.16 \times$ $10^{3} \mathrm{~m}^{2} \mathrm{~s} \mathrm{~s}^{-2}$. Compared with the climatological value in July, 3.72 $\times 10^{2} \mathrm{~m}^{2} \mathrm{~s}^{-2}$ (Chuda and Niino 2005), the sounding was modest unstable.

\section{Processing of radar data}

The EBN and KSR radars perform scans at 12 elevation angles, ranging from $0.7^{\circ}$ to $10.4^{\circ}$, every 5 minutes. In the present study, data from both radars are used for the retrieval of horizontal and vertical velocity. Reflectivity and polarimetric parameters are from the EBN radar. 


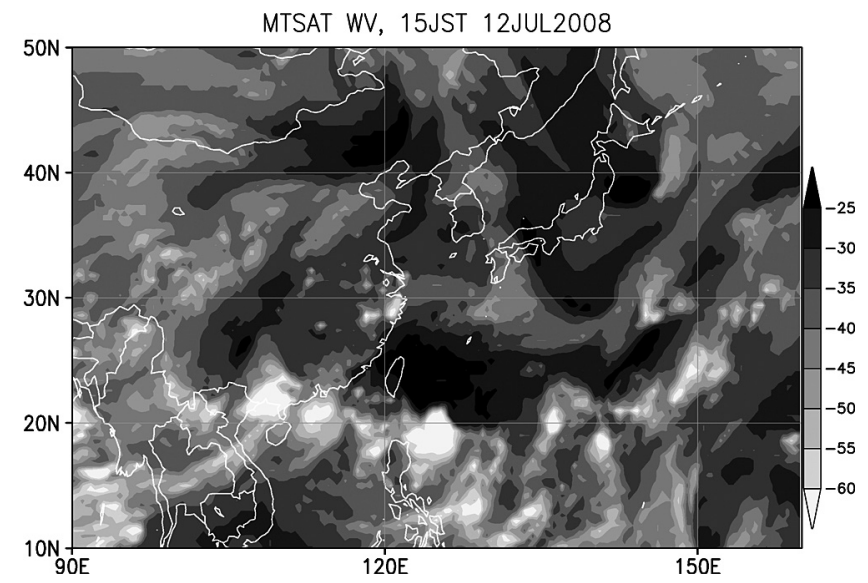

Fig. 2. IR3 image obtained by the Japanese Geostationary Satellite, MTSAT-1R, at 1500 JST on 12 July 2008. The grey scale shows the equivalent black-body temperature $\left(\mathrm{TBB},{ }^{\circ} \mathrm{C}\right)$. Image data were sourced from the Weather Home, Kochi University.

After calculation of the specific differential phase, $K_{\mathrm{DP}}$, simple attenuation-corrections for horizontal reflectivity, $Z_{\mathrm{H}}$, and differential reflectivity, $Z_{\mathrm{DR}}$, were made using empirical relationships between the one-way specific attenuation, $A_{\mathrm{H}}$ and $K_{\mathrm{DP}}$, and the specific differential attenuation, $A_{\mathrm{DP}}$ and $K_{\mathrm{DP}}$, taking into account their dependence on the elevation angles of the antenna. The empirical relationships were derived from the results of scattering simulations based on drop spectra measured by Park et al. (2005a) and Maki and Park (2009) using Joss-Waldvogel-type disdrometers in the Tsukuba area of Japan during June to December 2001. We also corrected the zero lag cross-correlation coefficient, $\rho_{\mathrm{HV}}$, according to the signal-to-noise ratio, and unfolded the Doppler velocity.

All PPI scan data were mapped to a Cartesian grid with a horizontal grid spacing of $0.0045^{\circ} \times 0.0055^{\circ}$ (about $500 \times 500 \mathrm{~m}$ ) and a vertical grid spacing of $500 \mathrm{~m}$, using Cressman interpolation. Three-dimensional wind in the Cartesian grids was estimated from Doppler velocities observed by two radars (Ray et al. 1980). Vertical velocity was calculated using a continuity equation with an adjustment procedure (O'Brien 1970). Vertical velocity was assumed to be zero at the ground and at $12.5 \mathrm{~km}$ height, where the height was the level of neutral buoyancy in the sounding profile (Fig. 3) and is assumed to be the cloud top.

\section{Results}

Figure 4 shows the horizontal distribution of the maximum $K_{\mathrm{DP}}$ from $1430 \mathrm{JST}$ to $1600 \mathrm{JST}$ at $1000 \mathrm{~m}$ above sea level (ASL), as observed by the EBN radar in Ebina City. The altitude of the eastern Tokyo is less than $100 \mathrm{~m}$. A value of $6^{\circ} \mathrm{km}^{-1}$ corresponds to a rainfall rate of $85.8 \mathrm{~mm} \mathrm{~h}^{-1}$ (Park et al. 2005b). The longitudinal zone of large $K_{\mathrm{DP}}$ from west Tokyo to east Tokyo reflects the path of the storm. Along the path, there are three regions where $K_{\mathrm{DP}}$ exceeds $6^{\circ} \mathrm{km}^{-1}$ : around Hino City (region A in Fig. 4), Setagaya Ward (region C), and Meguro Ward (region D). The storm passed these regions at around $1440 \mathrm{JST}, 1510 \mathrm{JST}$, and 1525 JST, respectively.

Figure 5 shows the horizontal distribution of the maximum wind speed observed by two multi-parameter radars at $500 \mathrm{~m}$ ASL. During this period, four regions of strong wind are recognized: eastern margin of Hino City (region A in Fig. 5), Chofu City (region B), Setagaya Ward (region C), and Minato Ward (region D). These regions are located to the east of regions of strong rainfall, and these gust winds occurred at the same time as strong rainfall, except for the case B where the gusts occurred at around 1500 JST. Based on these observations, the gust winds are inferred to have occurred on four separate occasions. The damage reported in the Tokyo Metropolitan Area may have resulted from

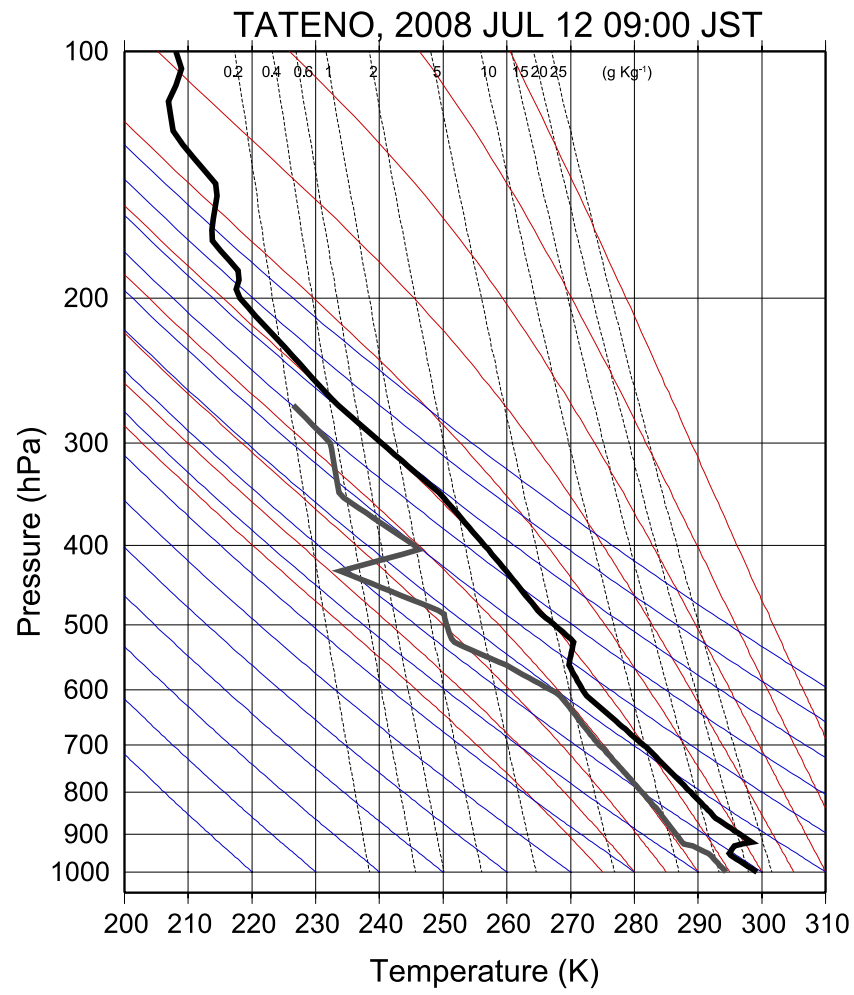

Fig. 3. Sounding taken at Tateno, Japan, at 0900 JST on 12 July 2008 Temperature is shown by the thick black line, and dew point by the thick gray line; reference wet adiabats (thin red lines) and reference dry adiabats (thin blue lines) were sourced from the Web page of the Department of Atmospheric Science, University of Wyoming, U.S.

the fourth gust wind, since the damaged area overlaped with the region $\mathrm{D}$ and the occurrence time of the damages corresponded to that of strong wind observed by the radars there.

The third strong wind labeled ' $\mathrm{C}$ ' was the strongest. Figure 6 shows horizontal wind vectors at $500 \mathrm{~m}$ ASL obtained from radar observations. A strong wind appeared in the northern part of Setagaya Ward, from $139^{\circ} 36^{\prime} \mathrm{E}$ to $139^{\circ} 42^{\prime} \mathrm{E}$, where the wind direction was westerly and near-uniform. These features exhibit forwardly deflected outburst wind associated with a traveling downburst (Fujita 1981).

Gust winds were observed at the ground. Figure 7 shows the time series of temperature, maximum wind speed, which is the maximum instantaneous wind speed during ten minutes up to the time, and wind direction observed at the Automated Meteorological Data Acquisition System (AMeDAS) station of Tokyo ( $35^{\circ}$ $41.4^{\prime} \mathrm{N}, 139^{\circ} 45.6^{\prime} \mathrm{E}$ and $6.1 \mathrm{~m} \mathrm{ASL}$ ). The surface maximum wind in Tokyo at $1400 \mathrm{JST}$ was southerly at $6.0 \mathrm{~m} \mathrm{~s}^{-1}$, relative humidity was $51 \%$ (not shown), and the temperature was $32.7^{\circ} \mathrm{C}$. At 1520 JST, maximum wind speed suddenly inceased from $4.3 \mathrm{~m} \mathrm{~s}^{-1}$ to 9.9 $\mathrm{m} \mathrm{s}^{-1}$ and it reached to the maximum value of $12.8 \mathrm{~m} \mathrm{~s}^{-1}$ in this day at 1530 JST. This gust wind should be related to the strong wind labeled 'D' in Fig. 5. Simultanously, temperature decreased from $31.8^{\circ} \mathrm{C}$ at $1520 \mathrm{JST}$ to $27.6^{\circ} \mathrm{C}$ at $1540 \mathrm{JST}$. These changes suggest that the strong gust wind was accompanied by cold air. Also in Fuchu City $\left(35^{\circ} 41.0^{\prime} \mathrm{N}, 139^{\circ} 28.9^{\prime} \mathrm{E}\right.$ and $59 \mathrm{~m}$ ASL), gust wind of $12.7 \mathrm{~m} \mathrm{~s}^{-1}$ was observed at 14:50 JST, which should be related to the strong wind labeled ' $\mathrm{B}$ ' (Fig. 5), and temperature decreased from $33.7^{\circ} \mathrm{C}$ at $14: 30$ JST to $23.9^{\circ} \mathrm{C}$ at $14: 50$ JST (not shown).

Figure 8 shows a vertical cross-section of derived velocities in this cross-section at 1510 JST. A strong downdraft is detected at $139^{\circ} 37^{\prime} \mathrm{E}$ and an updraft at $139^{\circ} 41^{\prime} \mathrm{E}$, corresponding to the western and eastern edges of the strong horizontal wind below $1.5 \mathrm{~km}$, respectively. This observation suggests that the downdraft brought 


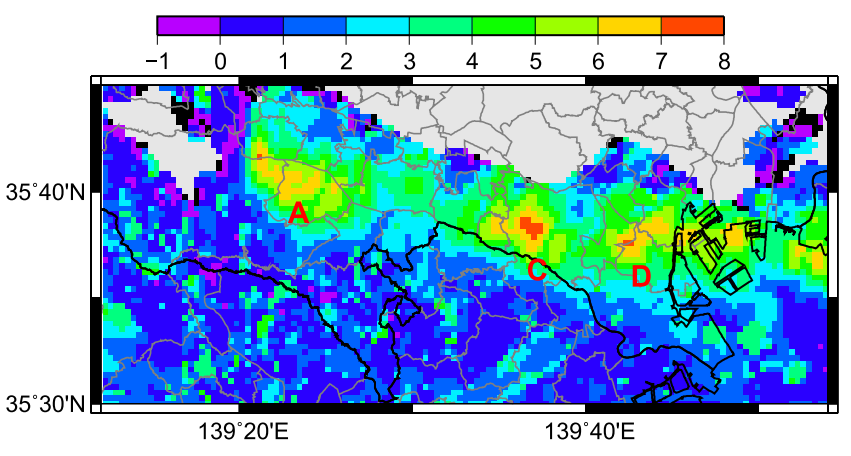

Fig. 4. Horizontal distribution of the maximum $K_{\mathrm{DP}}$ at $1000 \mathrm{~m}$ ASL between 1430 and $1600 \mathrm{JST}$, as observed by the EBN radar. The unit is ${ }^{\circ} \mathrm{km}^{-1}$. The letters A, C and D indicate the large $K_{\mathrm{DP}}$ regions referenced in the text.

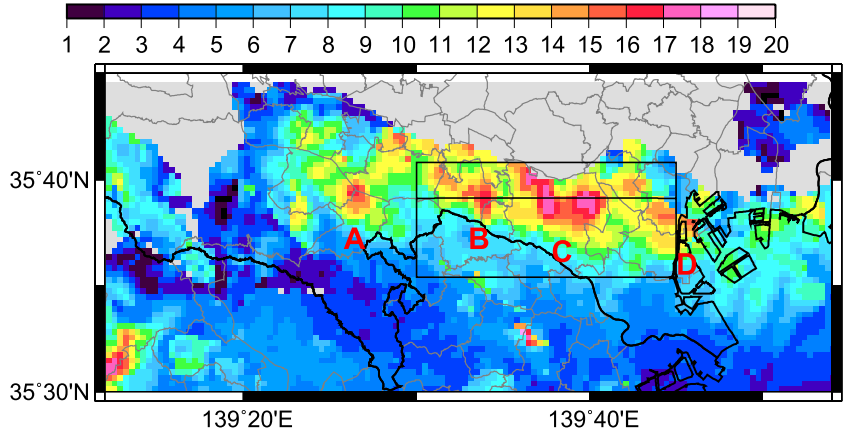

Fig. 5. Horizontal distribution of the maximum horizontal wind speed $\left(\mathrm{m} \mathrm{s}^{-1}\right)$ at $500 \mathrm{~m} \mathrm{ASL}$ between 1430 and $1600 \mathrm{JST}$, as observed by the EBN and KSR radars. The letters A, B, C and D indicate the regions of strong wind referenced in the text. A rectangle and solid line indicate the region of Fig. 6 and the position of Figs. 8 and 9.

about a strong horizontal wind and that the updraft was generated at the leading edge of the wind, i.e., the gust front.

Figure 8 also shows the rainfall rate, as calculated from $Z_{\mathrm{H}}$. There are two regions with high rates: a peak value of $120 \mathrm{~mm} \mathrm{~h}^{-1}$ in the lower troposphere under the downdraft, and a peak value of $140 \mathrm{~mm} \mathrm{~h}^{-1}$ at around $5 \mathrm{~km} \mathrm{ASL}$ in the updraft. Precipitation under the downdraft is suggested to have occurred via the 'falling' of hydrometeors. Hydrometeors were formed in the previous updraft in the middle and upper troposphere (not shown), and dissipated at this time. The other hydrometeors were developing in the updraft. A new convective cell was developing at the eastern edge of the gust front, generated from the other dissipating cell. This structure is typical of multi-cell systems.

The rainfall rate calculated from $K_{\mathrm{DP}}$ is shown in Fig. 9. Although $K_{\mathrm{DP}}$ is generally a good parameter, more than $Z_{\mathrm{H}}$ (Park et al. 2005b), with which to estimate the amount of rainfall as liquid water, it is insensitive to ice particles (e.g., Straka et al. 2000). The rainfall rate in the mid-troposphere, which is clearly defined in Fig. 8, was much lower than that calculated from $Z_{\mathrm{H}}$, indicating a large number of ice particles (i.e., hail).

Figure 9 also shows a vertical cross-section of $\rho_{\mathrm{HV}}$. Although $\rho_{\mathrm{HV}}$ is close to unity for most of the precipitation, it shows a marked decrease in the case of mixtures of hydrometeor types (Jameson 1989). In the downdraft, $\rho_{\mathrm{HV}}$ decreased at 2-4 km ASL. Although the rainfall rate calculated from $Z_{\mathrm{H}}$ showed a decrease below $2 \mathrm{~km}$ ASL, that calculated from $K_{\mathrm{DP}}$ showed an increase. These features support the interpretation that falling ice particles melted at this height. $\rho_{\mathrm{HV}}$ is also small at around $6 \mathrm{~km}$ ASL in the updraft. Considering the low rainfall rate calculated from $K_{\mathrm{DP}}$, a mixture of wet hail, raindrops, etc. is expected in this area. The melting of falling ice particles in the downdraft and freezing of condensed water in the updraft are clearly shown in the data from

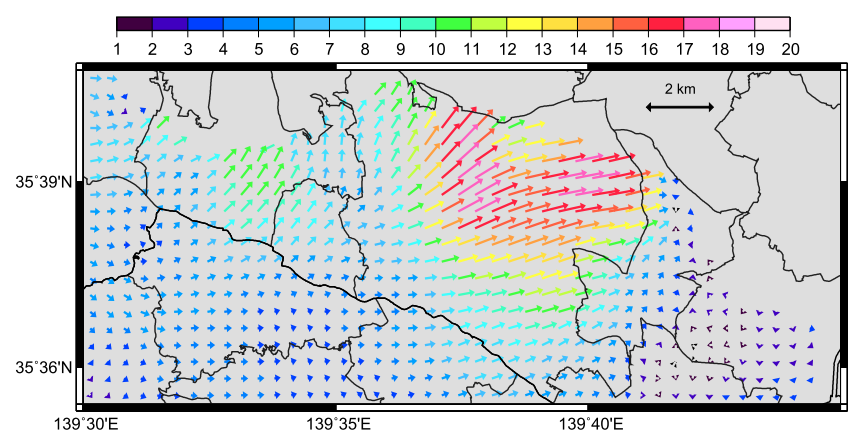

Fig. 6. Horizontal wind vectors at 1510 JST and $500 \mathrm{~m}$ ASL. Vector colors indicate wind speed $\left(\mathrm{m} \mathrm{s}^{-1}\right)$.

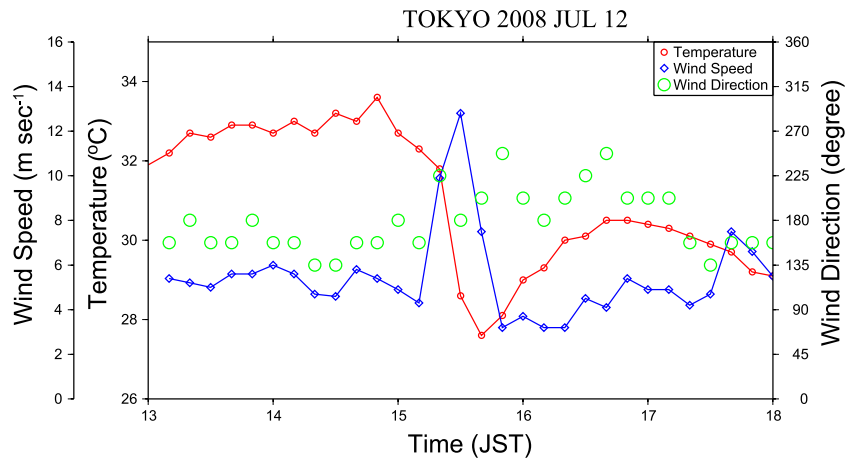

Fig. 7. Time series of temperature (red line), wind speed (blue line) and wind direction (green circles) observed at the Tokyo AMeDAS station on 12 July 2008.



Fig. 8. Vertical cross-section of rainfall rate (thin solid contours with an interval of $20 \mathrm{~mm} \mathrm{~h}^{-1}$ and thick contours for $100 \mathrm{~mm} \mathrm{~h}^{-1}$ ) calculated from $Z_{\mathrm{H}}$ and vertical velocity (color scale, $\mathrm{m} \mathrm{s}^{-1}$ ) at $1510 \mathrm{JST}$ and $35^{\circ} 39^{\prime} \mathrm{N}$.

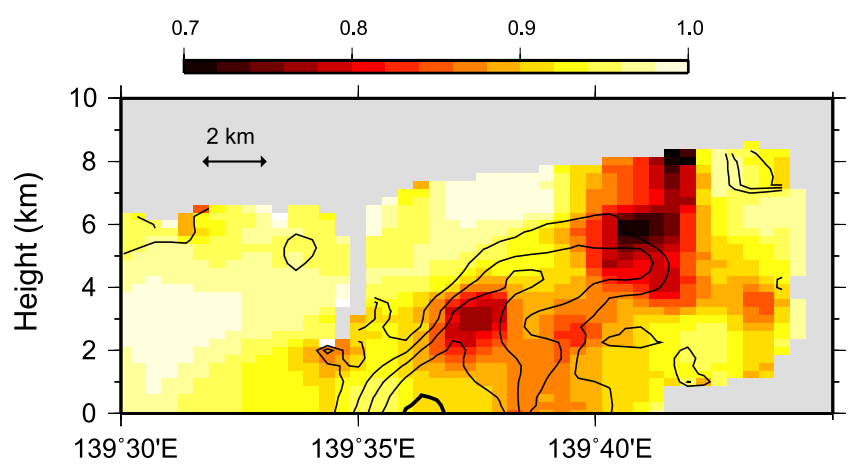

Fig. 9. Vertical cross-section of rainfall rate (solid contours with an interval of $20 \mathrm{~mm} \mathrm{~h}^{-1}$ and thick contours for $\left.100 \mathrm{~mm} \mathrm{~h}^{-1}\right)$ calculated from $K_{\mathrm{DP}}$ and $\rho_{\mathrm{HV}}$ (color scale) at $1510 \mathrm{JST}$ and $35^{\circ} 39^{\prime} \mathrm{N}$. 
the multi-parameter radar.

The other three events associated with strong winds labeled ' $A$ ', 'B' and ' $D$ ' also had similar time evolution. In the case of ' $B$ ', rainfall rate was not heavy as the other cases, however, a certain amount of hydrometeor in the middle troposphere and its descending were detected.

\section{Summary and discussion}

Two multi-parameter radars, located in Ebina and Kisarazu cities, provided good observations of strong convective storms and related downbursts that occurred over the Tokyo Metropolitan Area on 12 July 2008. The radars captured strong downdrafts in the mid-troposphere and diverging winds near the ground, suggesting that the storm produced downbursts. Four successive downbursts were observed during the active period of the convective cells, which showed features typical of multi-cell types, such as strong gust winds associated with downdrafts and updrafts generated at the gust fronts. This storm showed features typical of downbursts reported in Japan, as described in the statistical study performed by Ohno et al. (1996); i.e., wet downbursts that occurred repeatedly (in this case, four times) at around 1500 JST in July.

Srivastava (1987) investigated the effects of melting and evaporation on downdraft intensity using a one-dimensional numerical model, and arrived at the following conclusions. For temperature lapse rates close to dry-adiabatic, downbursts are possible under "dry" conditions and the phase of precipitation contents is unimportant. As the lapse rate becomes stable, a higher concentration of precipitation contents is required to drive a downburst. At 7.0 $\mathrm{K} \mathrm{km}{ }^{-1}$, a downburst can be driven by very heavy precipitation (rainfall rate $>100 \mathrm{~mm} \mathrm{~h}^{-1}$ ), although less-wet conditions are required if precipitation occurs as ice.

In the present study, the lapse rate at Tateno, Japan, as calculated from a sounding conducted at 0900 JST (Fig. 3), was 7.2 $\mathrm{K} \mathrm{km}^{-1}$ for $825-524 \mathrm{hPa}$. The downdrafts were strong at $2-6 \mathrm{~km}$ (e.g., Fig. 8) and it is suggested that falling ice particles would have melted completely near the surface, in the all four cases (not shown). The melting of ice particles would have been important for producing the downburst. Observations by multi-parameter radars revealed the structure of the downburst associated with the distributions of hydrometeors, including the existence of hail in the updraft, large amounts of liquid water in the downdraft, and phase changes of hydrometeors in downdrafts and updrafts.

At the time of the storm, the temperature in Fuchu City dropped by $9.8^{\circ}$ in just 20 minutes. The melting can not solely explain the strong cooling in the precipitation. Melting of 29.5 $\mathrm{g} \mathrm{kg}^{-1}$ ice, it is an unrealistic value (Srivastava 1987), is needed to the cooling. In addition to the effect of melting, the evaporation of precipitation also should be taken into account when explaining the occurance of the downburst.

\section{Acknowledgments}

Data for the GMS image were sourced from the Weather Home (Kochi University) and the Japan Meteorological Agency. The upper-air sounding data were sourced from the Web page of the Department of Atmospheric Science, University of Wyoming. We thank Dr. K. Kieda and Mr. M. Ikeda for assistance with processing the data.

\section{References}

Chuda, T., and H. Niino, 2005: Climatology of environmental parameters for mesoscale convections in Japan. J. Meteor. Soc. Japan, 83, 391-408.

Fujita, T. T., 1981: Tornadoes and downbursts in the context of generalized planetary scales. J. Atmos. Sci., 38, 1511-1534.

Jameson, A. R., 1989: The interpretation and meteorological application of radar backscatter amplitude ratios at linear polarizations. J. Atmos. Oceanic Technol., 6, 908-919.

Maki, M., and S.-G. Park, 2009: Rain rate estimators of X-band polarimetric radar scanning at high elevation angles. Report of the National Research Institute for Earth Science and Disaster Prevention, 73, 49-57, (in Japanese).

Maki, M., K. Iwanami, R. Misumi, S.-G. Park, H. Moriwaki, K.-I. Maruyama, I. Watabe, D.-I. Lee, M. Jang, H.-K. Kim, V. N. Bringi, and H. Uyeda, 2005: Semi-operational rainfall observations with X-band multi-parameter radar. Atmos. Sci. Lett., 6, 12-18.

O'Brien, J. J., 1970: Alternative solutions to the classical vertical velosity problem. J. Appl. Meteor., 9, 197-203.

Ohno, H., O. Suzuki, and K. Kusunoki, 1996: Climatology of downburst occurence in Japan. Tenki, 43, 101-112, (in Japanese).

Park, S.-G., V. N. Bringi, V. Chandrasekar, M. Maki, and K. Iwanami, 2005a: Correction of radar reflectivity and defferential reflectivity for rain attenuation at X band. Part I: Theoretical and empirical basis. J. Atmos. Oceanic Technol., 22, 1621-1632.

Park, S.-G., M. Maki, K. Iwanami, V. N. Bringi, and V. Chandrasekar, 2005b: Correction of radar reflectivity and defferential reflectivity for rain attenuation at X band. Part II: Evaluation and application. J. Atmos. Oceanic Technol., 22, $1633-1655$.

Proctor, F. H., 1989: Numerical simulations of an isolated microburst. Part II: Sensitivity experiments. J. Atmos. Sci., 46, 2143-2165.

Ray, S. P., C. L. Ziegler, W. Bumgarner, and R. J. Serafin, 1980: Single- and multiple-Doppler radar observations of tornadic storms. Mon. Wea. Rev., 108, 1607-1625.

Srivastava, R. C., 1987: A model of intense downdrafts driven by the melting and evaporation of precipitation. J. Atmos. Sci., 44, 1752-1773.

Straka, J. M., D. S. Zrnic, and A. V. Ryzhkov, 2000: Bulk hydrometeor classification and quantification using polarimetric radar data: Synthesis of relations. J. Appl. Meteor., 39, 1341 -1372 .

Tokyo District Meteorological Observatory, J. M. A., 2008: Report on the gust wind which occured in Shibuya, Meguro, Minato and Koutou Wards, Tokyo, on 12 July, 2008. Meteorological survey report on the natural disaster, $52 \mathrm{pp}$, (in Japanese).

Wakimoto, R. M., and V. N. Bringi, 1988: Dual-polarization observations of microbursts associated with intense convection: The 20 July Storm during the MIST Project. Mon. Wea. Rev., 116, 1521-1539.

Wilson, J. W., and R. M. Wakimoto, 2001: The discovery of the downburst: T. T. Fujita's contribution. Bull. Amer. Meteor. Soc., 82, 49-62.

Manuscript received 4 December 2009, accepted 9 March 2010 SOLA: http://www.jstage.jst.go.jp/browse/sola/ 